\title{
Beyond pollination: diversity of secretory structures during flower development in different legume lineages
}

\author{
Thais Cury De Barros ${ }^{1,2}$, Cristina Ribeiro Marinho², Giseli Donizete Pedersoli'², Juliana Vilella Paulino ${ }^{3}$ \\ and Simone Pádua Teixeira1,2,*
}

Received: August 11, 2016

Accepted: October 27, 2016

\begin{abstract}
Floral secretory structures are usually associated with the attraction of pollinators, but may also play an important role in the mechanisms of plant protection. This study aimed to show the diversity of secretory structures present in the developing flowers of 15 legume species belonging to different clades and to associate them with functions other than the pollinator attraction. Buds, flowers and developing axis of inflorescence were processed for surface, histological, and ultrastructural analyses. The species investigated displayed a wide diversity of secretory structures in developing flowers such as phenolic cells and/or tissues, mucilaginous cells, secretory cavities, secretory trichomes and colleters. Each type of secretory structure exhibited variation in morphology and location in the flower and/or axis of inflorescence depending on the species. Special mucilage cells, secretory cavities, secretory trichomes and colleters have great potential for comparative morphological studies due to their diversity of forms or restricted occurrence to certain taxa, contributing to a more robust morphological data base for the new clades emerging in Leguminosae. The scarcity of reports about floral secretory structures of Leguminosae seems to be more related to deficient sampling than to the absence of such structures in the group, which highlights the need for further investigation.
\end{abstract}

Keywords: anatomy, colleter, Fabaceae, gland, idioblast, Leguminosae, morphology, mucilage cells, secretory cavity, secretory trichome

\section{Introduction}

The flower is the fundamental structural unit for the successful reproduction of angiosperms. In order to protect the elements that act on the attraction of pollinators, plants have developed efficient floral organs during their development, such as bracts, bracteoles and sepals (Endress 1994). In addition to these organs, flowers can also have secretory structures that act on the defense mechanisms of the plant against herbivores, pathogens, UV light exposure and dehydration. Phenolic idioblasts, colleters and secretory cavities are some examples of secretory structures frequently associated with the protection of young organs such as those present in developing flowers (Fahn 1979). However, the secretory structures of flowers are usually associated with attraction and/or reward of pollinators, while their other functions such as protection have been neglected in the literature.

\footnotetext{
${ }^{1}$ Programa de Pós-Graduação em Biologia Comparada, Departamento de Biologia, Faculdade de Filosofia, Ciências e Letras de Ribeirão Preto, Universidade de São Paulo, Av. Bandeirantes, 3900, 14040-901, Ribeirão Preto, SP, Brazil

${ }^{2}$ Departamento de Ciências Farmacêuticas, Faculdade de Ciências Farmacêuticas de Ribeirão Preto, Universidade de São Paulo, Av. do Café, s/n., 14040-903, Ribeirão Preto, SP, Brazil

${ }^{3}$ Departamento de Produtos Naturais e Alimentos,Faculdade de Farmácia, Centro de Ciências da Saúde, Universidade Federal do Rio de Janeiro, Av. Prof Paulo Rocco s/n, Ilha do Fundão, 21941-902, Rio de Janeiro, RJ, Brazil

${ }^{*}$ Corresponding author: spadua@fcfrp.usp.br
} 
Leguminosae is the third largest angiosperm family, consisting of about 19,500 species and 751 genera (LPWG 2013). The beauty, diversity and highly interesting construction of their flowers have been the target of many anatomy and ontogeny studies (eg. Tucker 1994; 2000; 2003; Teixeira et al. 2009; Pedersoli et al. 2010; Paulino et al. 2013; 2014; Pedersoli \& Teixeira 2016). Thus, many reports about the floral secretory structures of this family would be expected to be available, whereas this is not the case. Studies of this nature are concentrated on nectaries (Bernadello 2007) and osmophores (Mansano \& Teixeira 2008; Marinho et al. 2014), secretory structures related to pollination, while other types such as secretory trichomes, idioblasts, cavities and ducts have been less explored in this family comprising such a wealth of species. The few examples available include studies of secretory trichomes in the floral parts of Bauhinia (Tucker 1984, Marinho et al. 2016) and Chamaecrista dentata (Meira et al. 2014), in the perianth of Indigofera (Kumar et al. 1986, Marquiafável et al. 2009), in the sepals of Dahlstedtia (Teixeira et al. 2009), in the ovary of Glycine (Healy et al. 2009), and in the bracteoles of Mimosa (Leelavathi et al. 1984); studies of the colleters in the bracts of Holocalyx balansae and Zollernia ilicifolia (Mansano \& Teixeira 2008) and Hymenaea stignocarpa (Paiva \& Machado 2006); of the secretory idioblasts in the perianth of Caesalpinia echinata (Teixeira \& Machado 2007) and in the ovary of Swartzia langsdorffii (Colpas \& Oliveira 2002); and studies of the secretory cavities in the perianth of Dahlstedtia (Teixeira \& Rocha 2009, Teixeira et al. 2009), in the ovary of Hymenaea stigonocarpa (Paiva \& Oliveira 2004), and of the secretory ducts and cavities in the petals and sepals of Pterodon pubescens, Dipteryx alata and Taralea oppositifolia (Leite et al. 2014).

Leguminosae is currently undergoing a process of reclassification and changes in its taxonomic hierarchy will probably occur, mainly regarding subfamilies and tribes. Traditionally, it is divided into the subfamilies Caesalpinioideae, Mimosoideae and Papilionoideae (Lewis et al. 2005). Caesalpinioideae is paraphyletic and positioned at the base of Leguminosae, with Mimosoideae and Papilionoideae derive from it, both of them monophyletic (LPWG 2013). After phylogenetic analyses pointed out the non-monophyly of many outstanding Leguminosae groups, a clear awareness was raised about the need to reassess the positioning of these groups (Luckow et al. 2000; 2003; Manzanilla \& Bruneau 2012; LPWG 2013). Within this context, the study of the diversity of floral secretory structures, especially those seldom reported in the literature, could provide important characters for systematics and contribute to a morphological database supporting and characterizing the emerging clades of Leguminosae.

Thus, the objective of the present study was to investigate the diversity of the secretory structures of developing flowers of 15 species of different Leguminosae clades. The expectation was to detect secretory structures little related to pollination whose morphology and distribution would be of help for the current classification of the family.

\section{Materials and methods}

\section{Species studied}

The morphological diversity of the secretory structures was investigated in flowers (Fig. 1) of 15 species of Leguminosae belonging to six different clades of the family (according to LPWG 2013) (Tab. 1).

\section{Collection and screening of the material}

Floral buds in various stages of development, flowers in the stage immediately preceding anthesis (pre-anthesis) and the developing axis of the inflorescence were collected, fixed in buffered formalin for $48 \mathrm{~h}$ (Lillie 1965) and dehydrated in an ethanol series. The materials were dissected with the aid of a stereomicroscope and screened for the presence of external secretory structures. Internal secretory structures formed during the early flower development were also investigated. After the initial screening, the materials were processed for surface (scanning electron microscopy) and anatomy exams (light microscopy).

\section{Surface analysis}

The surface of the external secretory structures of developing flowers was studied by scanning electron microscopy. To this end, previously fixed materials were dehydrated in an ethanol series (Tucker 1993), dried to the critical point with a Bal Tec CPD 030 apparatus, mounted on metal supports on an adhesive carbon tape and sputtered with gold with a BalTec SCD 050 sputter coater for 160 seconds. The observations were performed with a Zeiss IVO50 scanning microscope at $15 \mathrm{kv}$, and the photomicrographs were obtained with a coupled digital camera.

\section{Anatomy}

For the anatomical study, samples were dehydrated in ethanol series and embedded in histological resin (Gerrits 1991); longitudinal and cross sections with 1.5 to $3 \mu \mathrm{m}$ were obtained using a rotary microtome. Serial sections were stained with $0.05 \%$ Toluidine Blue in phosphate buffer, pH 5.8 (O'Brien et al. 1964), mounted in water and observed under a light microscope. The photomicrographs were obtained with a Leica DM 4500 B photomicroscope coupled to a Leica DFC 320 digital camera, with scales under the same optical conditions. 

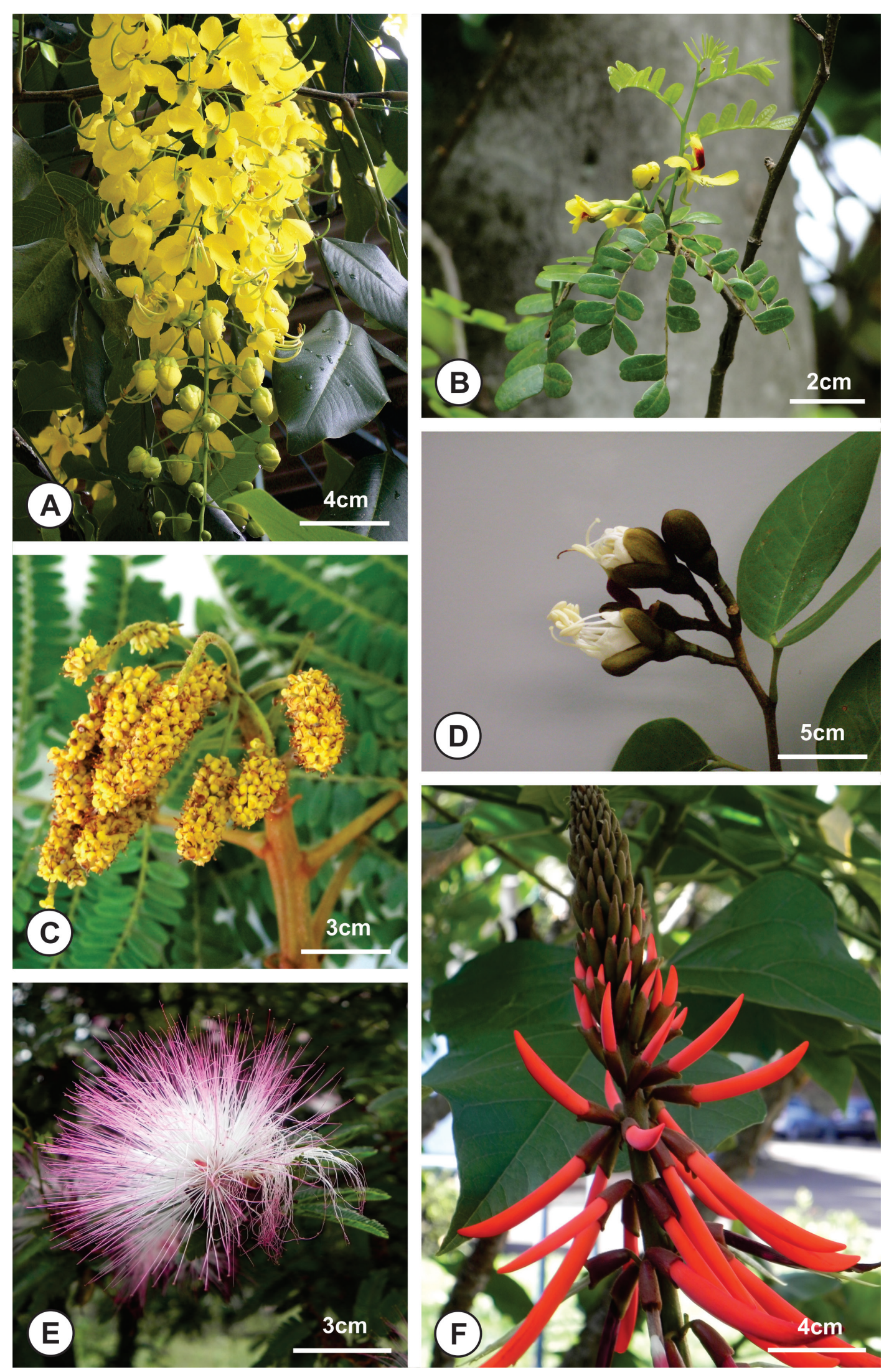

Figure 1. Flowers of six legume species representing each of the six clades sampled in this study. A. Cassia fistula (Cassia clade). B. Caesalpinia echinata (Caesalpinia clade). C. Dimorphandra mollis (Dimorphandra p.p clade). D. Hymenaea courbaril (Detarieae clade). E. Calliandra brevipes (Mimosoideae clade). F. Erythrina speciosa (Papilionoideae clade). 
Table 1. Leguminosae species sampled in this study. Shown are the species clade, species name, voucher and acronyms of herbaria where vouchers are housed.

\begin{tabular}{|c|c|c|c|c|c|}
\hline Clade & Species & Collection site & Natural habitat & Voucher & Herbarium \\
\hline Cassia clade & Cassia fistula L. & $\begin{array}{l}\text { Ribeirão Preto, SP } \\
\text { (campus da USP) }\end{array}$ & Tropical and subtropical forest & JV Paulino 13 & SPFR \\
\hline Caesalpinia clade & Caesalpinia echinata Lam. & $\begin{array}{l}\text { Ribeirão Preto, SP } \\
\text { (campus da USP) }\end{array}$ & Atlantic Rainforest & SP Teixeira 67 & SPFR \\
\hline $\begin{array}{l}\text { Dimorphandra p.p. } \\
\text { clade }\end{array}$ & Dimorphandra mollis Benth. & $\begin{array}{c}\text { São Carlos, SP } \\
\text { (original vegetation) }\end{array}$ & Brazilian savanna & TC Barros 20 & SPFR \\
\hline Detarieae clade & Hymenaea courbaril L. & $\begin{array}{l}\text { Ribeirão Preto, SP } \\
\text { (campus da USP) }\end{array}$ & Brazilian savanna & SP Teixeira 45 & SPFR \\
\hline Mimosoideae clade & Calliandra brevipes Benth. & $\begin{array}{l}\text { Ribeirão Preto, SP } \\
\text { (campus da USP) }\end{array}$ & $\begin{array}{l}\text { Amazonian Rainforest, } \\
\text { Caatinga, Brazilian savanna, } \\
\text { Atlantic Rainforest, Pampas }\end{array}$ & SP Teixeira 77 & SPFR \\
\hline Mimosoideae clade & Inga bella M. Sousa & $\begin{array}{c}\text { Costa Rica } \\
\text { (original vegetation) }\end{array}$ & Tropical forest & R Aguilar 12746 & SPFR \\
\hline Mimosoideae clade & Mimosa lewisii Barneby & $\begin{array}{l}\text { Morro do Chapéu, BA } \\
\text { (original vegetation) }\end{array}$ & Caatinga & SP Teixeira 76 & SPFR \\
\hline Mimosoideae clade & $\begin{array}{c}\text { Tetrapleura tetraptera } \\
\text { (Schumach. \& Thonn.) Taub. }\end{array}$ & $\begin{array}{l}\text { Jardim Botânico do Rio de } \\
\text { Janeiro, RJ (cultivated) }\end{array}$ & West African Rainforest & TC Barros 05 & SPFR \\
\hline Papilionoideae clade & Erythrina speciosa Andrews & $\begin{array}{l}\text { Ribeirão Preto, SP } \\
\text { (campus da USP) }\end{array}$ & $\begin{array}{l}\text { Brazilian savanna, Atlantic Rain- } \\
\text { forest }\end{array}$ & TC Barros 33 & SPFR \\
\hline Papilionoideae clade & $\begin{array}{l}\text { Gliricidia sepium (Jacq.) } \\
\text { Kunth ex Walp. }\end{array}$ & $\begin{array}{l}\text { Ribeirão Preto, SP } \\
\text { (campus da USP) }\end{array}$ & $\begin{array}{c}\text { Amazonian Rainforest, Caatinga, } \\
\text { Brazilian savanna, Atlantic Rain- } \\
\text { forest }\end{array}$ & SP Teixeira 62 & SPFR \\
\hline Papilionoideae clade & $\begin{array}{c}\text { Indigofera lespedezioides } \\
\text { Kunth }\end{array}$ & $\begin{array}{l}\text { Ribeirão Preto, SP } \\
\text { (campus da USP) }\end{array}$ & $\begin{array}{l}\text { Amazonian Rainforest, Brazilian } \\
\text { savanna, Atlantic Rainforest }\end{array}$ & $\begin{array}{l}\text { MS Ogasawara } \\
9926\end{array}$ & SPFR \\
\hline Papilionoideae clade & Leptolobium elegans Vogel & Campinas, SP & $\begin{array}{c}\text { Amazonian Rainforest, } \\
\text { Brazilian savanna }\end{array}$ & $\begin{array}{l}\text { RS Rodrigues \& A } \\
\text { Flores } 993\end{array}$ & UEC \\
\hline Papilionoideae clade & Mucuna urens (L.) Medik. & $\begin{array}{l}\text { BR } 101 \mathrm{~km} 11-13 \\
\text { (original vegetation) }\end{array}$ & Atlantic Rainforest & SP Teixeira 58 & SPFR \\
\hline Papilionoideae clade & Platycyamus regnellii Benth. & $\begin{array}{l}\text { Ribeirão Preto, SP } \\
\text { (campus da USP) }\end{array}$ & $\begin{array}{l}\text { Brazilian savanna, Atlantic Rain- } \\
\text { forest }\end{array}$ & SP Teixeira 54 & SPFR \\
\hline Papilionoideae clade & $\begin{array}{l}\text { Tipuana tipu (Benth.) } \\
\text { Kuntze }\end{array}$ & $\begin{array}{l}\text { Ribeirão Preto, SP } \\
\text { (campus da USP) }\end{array}$ & $\begin{array}{c}\text { Brazilian savanna, Atlantic Rain- } \\
\text { forest }\end{array}$ & SP Teixeira 51 & SPFR \\
\hline
\end{tabular}

\section{Ultrastructure}

To ensure the type of mucilage cell, sepal samples of Mimosa lewisii were collected, fixed in Karnovsky's solution for $24 \mathrm{~h}$ (Karnovsky 1965) and stored in $0.1 \mathrm{M}$ phosphate buffer, pH 7.2, at $4{ }^{\circ} \mathrm{C}$. The samples were postfixed in $1 \%$ osmium tetroxide for $2 \mathrm{~h}$ at $4{ }^{\circ} \mathrm{C}$, and then washed in distilled water, dehydrated, embedded in Araldite resin and cut into ca. $70 \mathrm{~nm}$ thick sections. The obtained sections were stained with $2 \%$ uranyl acetate for 25 min and lead citrate for $5 \mathrm{~min}$. (Reynolds 1963), observed and ilustrated in a Jeol 100CX II transmission electron microscope.

\section{Results}

The Leguminosae species belonging to all six clades investigated (Cassia, Caesalpinia, Dimorphandra p.p., Detarieae, Mimosoideae and Papilionoideae clades) display several types of secretory structures in the developing flower and in the developing axis of the inflorescence (Fig. 2, Tab. 2): phenolic cells and/or tissues, mucilaginous epidermis, secretory cavities and secretory trichomes. Each type of secretory structure may vary in morphology and location in the flower and/or in the axis of inflorescence, and according to the clade that the species belongs. 


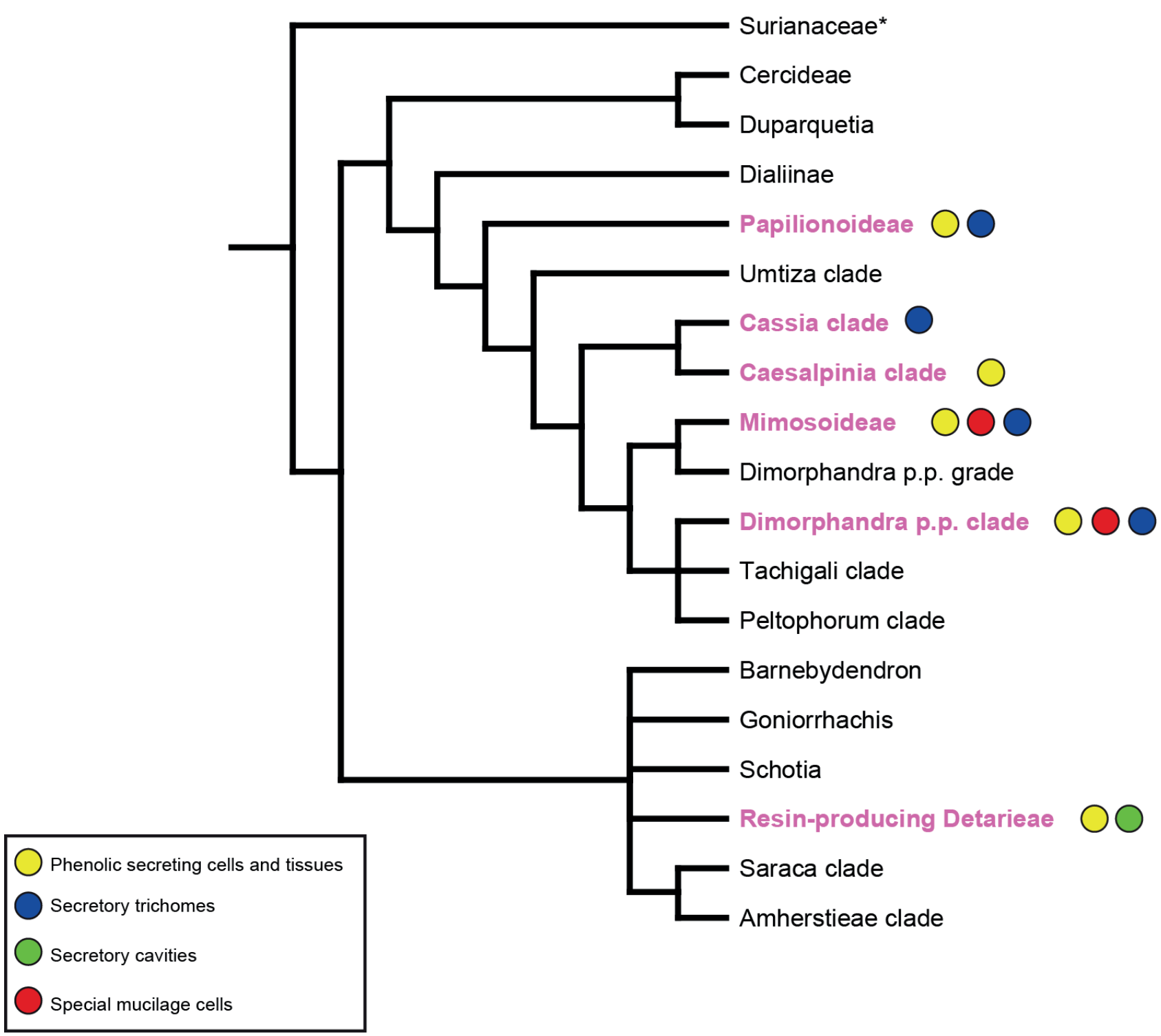

Figure 2. Phylogenetic relations among the clades studied in the present investigation (in lilac) based on LPWG (2013). The occurrence of the various types of secretory structures detected in the Leguminosae species studied was marked in the topography. Please see the PDF version for color reference.

Voluminous and sparse phenolic cells characterizing phenolic idioblasts are found in five out of six analyzed clades (Fig. 2, Tab. 2). They occur close to the vascular bundles of the sepals, petals, stamens and carpel (Fig. 3A) and in the cortex of the axis of inflorescence (Fig. 3B). These cells may be grouped in the subepidermal layers on the abaxial surface of the sepals (Fig. 3C, D), in the epidermis of the sepals (Fig. 3C, D), in the mesophilic parenchyma of the sepals and carpel (Fig. 3E), and in the cortical and medullary parenchyma of the axis of inflorescence (Fig. 3F).

Voluminous cells with a mucilaginous inner cell wall and a distinct cytoplasm are found in Dimorphandra p.p. and Mimosoideae clades (Fig. 2, Tab. 2). They can be filled of phenolic compounds and form the epidermis of bracts and sepals (Fig. 4A-F).
Secretory cavities, consisting of a single epithelium layer of secretory papillose cells, delimiting a rounded lumen, are found in Detarieae clade (Fig. 2, Tab. 2). They occur in the mesophyll of the sepals (Fig. 5A, B) and petals (Fig. $5 C, D$ ). In both section planes analyzed (longitudinal and transversal) the lumen maintains the rounded shape, which supports the classification of secretory cavity.

Secretory trichomes are found in four out of six analyzed clades (Cassia, Dimorphandra p.p., Mimosoideae and Mimosoideae clades - Fig. 2, Tab. 2). They occur in the axis of inflorescence, in the bracts, at the base of the flower bud, and in the sepals, petals and carpel. They are usually numerous and grouped when present between the axis of inflorescence and the base of the flower bud. The trichomes 
Table 2. Diversity of the secretory structures detected in developing flowers and axis of the inflorescence of the Leguminosae species studied.

\begin{tabular}{|c|c|c|c|c|c|}
\hline $\begin{array}{l}\text { Traditional } \\
\text { subfamily }\end{array}$ & Clade & Species & $\begin{array}{l}\text { Secretory } \\
\text { structures }\end{array}$ & Location & Morphology of the secretory structures \\
\hline Caesalpinioideae & Cassia clade & Cassia fistula & $\begin{array}{l}\text { Secretory } \\
\text { trichomes }\end{array}$ & $\begin{array}{l}\text { - Axis of the inflorescence, base } \\
\text { of the floral receptacle and the } \\
\text { margins of bracts and bracteoles }\end{array}$ & $\begin{array}{l}\text { - Grouped multicellular trichomes with no } \\
\text { apparent distinction between peduncle and } \\
\text { head - colleter (Fig. 6A, C) }\end{array}$ \\
\hline Caesalpinioideae & $\begin{array}{l}\text { Caesalpinia } \\
\text { clade }\end{array}$ & $\begin{array}{l}\text { Caesalpinia } \\
\text { echinata }\end{array}$ & $\begin{array}{l}\text { Phenolic cells } \\
\text { and tissues }\end{array}$ & $\begin{array}{l}\text { - Phenolic idioblasts in the } \\
\text { mesophyll of bracts, sepals and } \\
\text { petals } \\
\text { - Phenolic epidermis in the sepals }\end{array}$ & $\begin{array}{l}\text { - Voluminous idioblasts with the vacuole } \\
\text { filled with phenolic compounds occupying the } \\
\text { entire cell volume (Fig. } 2 \text { C) } \\
\text { - Phenolic epidermis consistting of less } \\
\text { voluminous cells than idioblasts, with the } \\
\text { vacuole filled with phenolic compounds } \\
\text { occupying the entire cell volume (Fig. } 2 \text { C) }\end{array}$ \\
\hline \multirow{3}{*}{ Caesalpinioideae } & \multirow{3}{*}{$\begin{array}{l}\text { Dimorphandra } \\
\text { p.p. clade }\end{array}$} & \multirow{3}{*}{$\begin{array}{l}\text { Dimorphandra } \\
\text { mollis }\end{array}$} & $\begin{array}{c}\text { Mucilaginous } \\
\text { epidermis }\end{array}$ & - Bract and sepals & $\begin{array}{l}\text { - Voluminous cells with thick walls largely } \\
\text { consisting of mucilage and a distinct } \\
\text { cytoplasm (Fig. 3A, B) }\end{array}$ \\
\hline & & & $\begin{array}{l}\text { Phenolic cells } \\
\text { and tissues }\end{array}$ & $\begin{array}{l}\text { - Phenolic cells grouped in the } \\
\text { subepidermal layers (cortex) of } \\
\text { the axis of inflorescence } \\
\text { - Phenolic epidermis of petals } \\
\text { and carpel } \\
\text { - Phenolic parenchyma } \\
\text { (mesophyll) of bracts, sepals, } \\
\text { petals and carpel }\end{array}$ & $\begin{array}{l}\text { - The phenolic cells of the axis of the } \\
\text { inflorescence, bract, sepals and carpel are } \\
\text { voluminous and their vacuoles are filled with } \\
\text { phenolic compounds occupying the entire cell } \\
\text { volume (Figs. 2E, 3A) } \\
\text { - Cells of the petal parenchyma and epidermis } \\
\text { and of the carpel are more isodiametric and } \\
\text { have a smaller vacuole (Figs. 2E, 3A) }\end{array}$ \\
\hline & & & $\begin{array}{l}\text { Secretory } \\
\text { trichomes }\end{array}$ & - Axis of the inflorescence & $\begin{array}{l}\text { - Usually grouped with a multicellular and } \\
\text { multiseriate peduncle narrower than the } \\
\text { multicellular secretory head consisting } \\
\text { of voluminous cells; presence of phenolic } \\
\text { compounds in the cells of the peduncle. }\end{array}$ \\
\hline & & & $\begin{array}{l}\text { Secretory } \\
\text { cavities }\end{array}$ & - Mesophyll of sepals and petals & $\begin{array}{l}\text { - Secretory cavities with epithelium consisting } \\
\text { of a layer of secretory cells delimiting a lumen } \\
\text { (Fig. 4A-D). }\end{array}$ \\
\hline Caesalpinioideae & Detarieae clade & $\begin{array}{c}\text { Hymenaea } \\
\text { courbaril }\end{array}$ & $\begin{array}{l}\text { Phenolic cells } \\
\text { and tissues }\end{array}$ & $\begin{array}{l}\text { - Phenolic epidermis } \\
\text { of sepals and petals } \\
\text { - Phenolic parenchyma } \\
\text { of sepals and petals }\end{array}$ & $\begin{array}{l}\text { - The phenolic cells of the epidermis are more } \\
\text { rectangular and smaller than the phenolic } \\
\text { cells of the parenchyma (Fig. 3A-D) } \\
\text { - The phenolic cells of the parenchyma } \\
\text { of sepals and petals have a vacuole filled } \\
\text { with phenolic compounds and are more } \\
\text { voluminous when located close to the } \\
\text { secretory cavities (Fig. 3A-D) }\end{array}$ \\
\hline \multirow[t]{2}{*}{ Mimosoideae } & \multirow[t]{2}{*}{$\begin{array}{l}\text { Mimosoideae } \\
\text { clade }\end{array}$} & \multirow[t]{2}{*}{$\begin{array}{l}\text { Calliandra } \\
\text { brevipes }\end{array}$} & $\begin{array}{l}\text { Phenolic cells } \\
\text { and tissues }\end{array}$ & $\begin{array}{l}\text { - Phenolic cells grouped in the } \\
\text { subepidermal layers of the } \\
\text { abaxial surface of bract, sepals } \\
\text { and petals } \\
\text { - Phenolic parenchyma of the } \\
\text { cortex and medulla of the axis of } \\
\text { the inflorescence }\end{array}$ & $\begin{array}{l}\text { - Voluminous phenolic cells with a vacuole } \\
\text { filled with phenolic compounds in the } \\
\text { subepidermal layers of the abaxial surface } \\
\text { of bract, sepals and petals (Fig. 2D) } \\
\text { - Phenolic epidermis consisting of } \\
\text { rectangular cells smaller than the cells of the } \\
\text { subepidermal layers } \\
\text { - Parenchymal cells with a vacuole filled with } \\
\text { phenolic compounds, more voluminous in the } \\
\text { medulla than in the cortex (Fig. 2F) }\end{array}$ \\
\hline & & & $\begin{array}{l}\text { Secretory } \\
\text { trichomes }\end{array}$ & $\begin{array}{l}\text { - Axis of the inflorescence, bract, } \\
\text { margins of sepals and petals }\end{array}$ & $\begin{array}{l}\text { - Trichomes with a multicellular and } \\
\text { uniseriate peduncle narrower than the } \\
\text { multicellular secretory head with more } \\
\text { voluminous cells; phenolic compounds } \\
\text { present in the vacuole of cells of the peduncle } \\
\text { and head (Fig. 4A, B) }\end{array}$ \\
\hline Mimosoideae & $\begin{array}{l}\text { Mimosoideae } \\
\text { clade }\end{array}$ & Inga bella & $\begin{array}{l}\text { Secretory } \\
\text { trichomes }\end{array}$ & - Margins of bract and sepals & $\begin{array}{l}\text { - Trichomes with a multicellular and uniseriate } \\
\text { peduncle narrower than the secretory head, } \\
\text { which is also multicellular (Fig. 5C, D) }\end{array}$ \\
\hline
\end{tabular}




\section{Thais Cury De Barros, Cristina Ribeiro Marinho, Giseli Donizete Pedersoli, Juliana Vilella Paulino and Simone Pádua Teixeira}

Table 2. Cont.

\begin{tabular}{|c|c|c|c|c|c|}
\hline $\begin{array}{l}\text { Traditional } \\
\text { subfamily }\end{array}$ & Clade & Species & $\begin{array}{l}\text { Secretory } \\
\text { structures }\end{array}$ & Location & Morphology of the secretory structures \\
\hline \multirow{3}{*}{ Mimosoideae } & \multirow{3}{*}{$\begin{array}{l}\text { Mimosoideae } \\
\text { clade }\end{array}$} & \multirow{3}{*}{$\begin{array}{c}\text { Mimosa } \\
\text { lewisii }\end{array}$} & $\begin{array}{l}\text { Mucilaginous } \\
\text { epidermis }\end{array}$ & - Sepal & $\begin{array}{l}\text { - Voluminous cells with thick walls largely } \\
\text { consisting of mucilage and a distinct } \\
\text { cytoplasm (Fig. } 3 \text { C-F) }\end{array}$ \\
\hline & & & $\begin{array}{l}\text { Phenolic cells } \\
\text { and tissues }\end{array}$ & $\begin{array}{l}\text { - Phenolic cells in the mesophyll } \\
\text { of the axis of the inflorescence, } \\
\text { bract, sepal and carpel } \\
\text { - Phenolic epidermis of the sepals }\end{array}$ & $\begin{array}{l}\text { - Voluminous phenolic idioblasts with a } \\
\text { vacuole filled with sparse phenolic compounds } \\
\text { in the mesophyll of the sepal (Fig. 3D) } \\
\text { - Phenolic cells grouped in the subepidermal } \\
\text { layers of the bract } \\
\text { - Phenolic epidermis on the abaxial surface of } \\
\text { the sepal consisting of voluminous cells with } \\
\text { a vacuole filled with phenolic compounds (Fig. } \\
\text { 3E, F) }\end{array}$ \\
\hline & & & $\begin{array}{l}\text { Secretory } \\
\text { trichomes }\end{array}$ & $\begin{array}{l}\text { - Axis of the inflorescence and } \\
\text { bract }\end{array}$ & $\begin{array}{l}\text { - Large secretory trichomes with a robust } \\
\text { peduncle and a small head; peduncle with } \\
\text { accumulation of phenolic compounds (Fig. } \\
5 \mathrm{E}, \mathrm{F} \text { ) } \\
\text { - Secretory trichomes of phenolic compounds, } \\
\text { with no apparent distinction between } \\
\text { peduncle and head - colleter (Fig. } 6 \mathrm{~F} \text { ) }\end{array}$ \\
\hline Mimosoideae & $\begin{array}{l}\text { Mimosoideae } \\
\text { clade }\end{array}$ & $\begin{array}{l}\text { Tetrapleura } \\
\text { tetraptera }\end{array}$ & $\begin{array}{l}\text { Secretory } \\
\text { trichomes }\end{array}$ & - Base of the flower bud & $\begin{array}{l}\text { - Trichomes with a multicellular and } \\
\text { multiseriate peduncle narrower than the } \\
\text { multicellular secretory head and with more } \\
\text { voluminous cells; phenolic compounds } \\
\text { present in the vacuoles of the cells of the } \\
\text { peduncle (Fig. 5G, H) }\end{array}$ \\
\hline Papilionoideae & $\begin{array}{l}\text { Papilionoideae } \\
\text { clade }\end{array}$ & $\begin{array}{l}\text { Leptolobium } \\
\text { elegans }\end{array}$ & $\begin{array}{l}\text { Secretory } \\
\text { trichomes }\end{array}$ & $\begin{array}{l}\text { - Axilla of the bracts, bracteoles } \\
\text { and axis of the inflorescence }\end{array}$ & $\begin{array}{l}\text { - Grouped multicellular trichomes with no } \\
\text { apparent distinction between peduncle and } \\
\text { head - colleter (Fig. } 6 \text { B) }\end{array}$ \\
\hline \multirow[b]{2}{*}{ Papilionoideae } & \multirow[b]{2}{*}{$\begin{array}{l}\text { Papilionoideae } \\
\text { clade }\end{array}$} & \multirow[b]{2}{*}{$\begin{array}{l}\text { Erythrina } \\
\text { speciosa }\end{array}$} & Phenolic cells & $\begin{array}{l}\text { - Mesophyll of the sepals and } \\
\text { stamen filament }\end{array}$ & $\begin{array}{l}\text { - Sparse and non-voluminous idioblasts close } \\
\text { to the vascular bundles }\end{array}$ \\
\hline & & & $\begin{array}{l}\text { Secretory } \\
\text { trichomes }\end{array}$ & - Sepals & $\begin{array}{l}\text { - Trichomes with a multicellular and } \\
\text { uniseriate peduncle with no apparent } \\
\text { distinction from the more voluminous } \\
\text { multicellular secretory head }\end{array}$ \\
\hline \multirow{2}{*}{ Papilionoideae } & \multirow{2}{*}{$\begin{array}{l}\text { Papilionoideae } \\
\text { clade }\end{array}$} & \multirow{2}{*}{$\begin{array}{l}\text { Gliricidia } \\
\text { sepium }\end{array}$} & Phenolic cells & $\begin{array}{l}\text { - Mesophyll of the axis of the } \\
\text { inflorescence, sepals and carpel }\end{array}$ & $\begin{array}{l}\text { - Sparse and very voluminous idioblasts with } \\
\text { a vacuole filled with phenolic compounds } \\
\text { occupying the entire cell volume (Fig. 2B) }\end{array}$ \\
\hline & & & $\begin{array}{l}\text { Secretory } \\
\text { trichomes }\end{array}$ & $\begin{array}{l}\text { - Axis of the inflorescence, base } \\
\text { of the flower bud }\end{array}$ & $\begin{array}{l}\text { - Multicellular trichomes with no apparent } \\
\text { distinction between peduncle and head - } \\
\text { colleter (Fig. 6E) }\end{array}$ \\
\hline Papilionoideae & $\begin{array}{l}\text { Papilionoideae } \\
\text { clade }\end{array}$ & $\begin{array}{l}\text { Indigofera } \\
\text { lespedezioides }\end{array}$ & $\begin{array}{l}\text { Secretory } \\
\text { trichomes }\end{array}$ & $\begin{array}{l}\text { - Axilla of the bracts, bracteoles } \\
\text { and axis of the inflorescence }\end{array}$ & $\begin{array}{l}\text { - Grouped multicellular trichomes with no } \\
\text { apparent distinction between peduncle and } \\
\text { head - colleter }\end{array}$ \\
\hline \multirow[b]{2}{*}{ Papilionoideae } & \multirow{2}{*}{$\begin{array}{l}\text { Papilionoideae } \\
\text { clade }\end{array}$} & \multirow[b]{2}{*}{ Mucuna urens } & Phenolic cells & $\begin{array}{l}\text { - Mesophyll of the sepals and } \\
\text { stamen filament }\end{array}$ & $\begin{array}{l}\text { - Non-voluminous phenolic idioblasts close to } \\
\text { the vascular bundles }\end{array}$ \\
\hline & & & $\begin{array}{l}\text { Secretory } \\
\text { trichomes }\end{array}$ & $\begin{array}{l}\text { - Base of the flower bud and } \\
\text { sepals }\end{array}$ & $\begin{array}{l}\text { - Trichomes with a multicellular and } \\
\text { uniseriate peduncle narrower than the } \\
\text { multicellular head }\end{array}$ \\
\hline \multirow{3}{*}{ Papilionoideae } & \multirow[b]{2}{*}{$\begin{array}{l}\text { Papilionoideae } \\
\text { clade }\end{array}$} & \multirow[b]{2}{*}{$\begin{array}{l}\text { Platycyamus } \\
\text { regnellii }\end{array}$} & Phenolic cells & $\begin{array}{l}\text { - Mesophyll of the sepals, stamen } \\
\text { filament and carpel }\end{array}$ & $\begin{array}{l}\text { - Non-voluminous phenolic idioblasts close to } \\
\text { the vascular bundles }\end{array}$ \\
\hline & & & $\begin{array}{l}\text { Secretory } \\
\text { trichomes }\end{array}$ & - Bract, sepals and carpel & $\begin{array}{l}\text { - Trichomes with a multicellular and } \\
\text { uniseriate peduncle narrower than the } \\
\text { multicellular head - colleter (Fig. 6D) }\end{array}$ \\
\hline & $\begin{array}{l}\text { Papilionoideae } \\
\text { clade }\end{array}$ & $\begin{array}{l}\text { Tipuana } \\
\text { tipu }\end{array}$ & Phenolic cells & $\begin{array}{l}\text { - Mesophyll of the sepals, petals, } \\
\text { stamen filament and carpel wall }\end{array}$ & $\begin{array}{l}\text { - Sparse and very voluminous idioblasts with } \\
\text { the vacuole filled with phenolic compounds } \\
\text { occupying the entire cell volume and } \\
\text { concentrated close to the vascular bundles or } \\
\text { in the subepidermal layers of the sepals (Fig. } \\
\text { 2A) }\end{array}$ \\
\hline
\end{tabular}



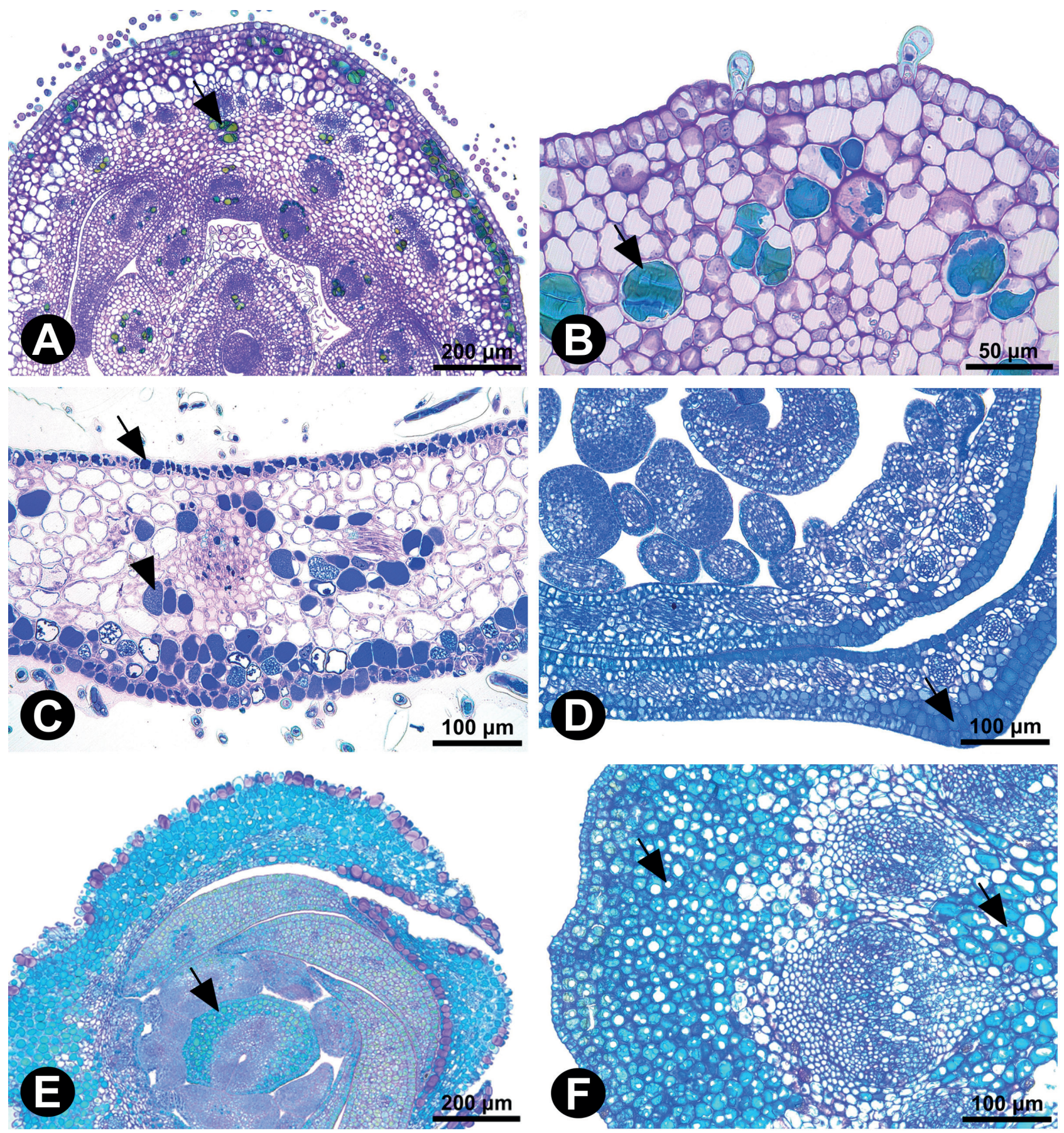

Figure 3. Occurrence of phenolic cells and tissues in Leguminosae species. A. Phenolic idioblasts (arrow) close to the vascular bundles of the sepals, petals, stamens and carpel of Tipuana tipu. B. Sparse phenolic idioblasts (arrow) in the cortex of the developing axis of inflorescence in Gliricidia sepium. C. Phenolic cells grouped in the epidermis (arrow) on the abaxial surface of the sepal in Caesalpinia echinata. Note the phenolic idioblasts in the mesophyll (arrow head). D. Phenolic cells (arrow) grouped in the subepidermal layers on the abaxial surface of the sepal in Calliandra brevipes. E. Phenolic cells (arrow) forming the mesophyll of the sepals in Dimorphandra mollis. F. Phenolic cells (arrow) forming the cortex and pith of the axis of inflorescence in Calliandra brevipes. 

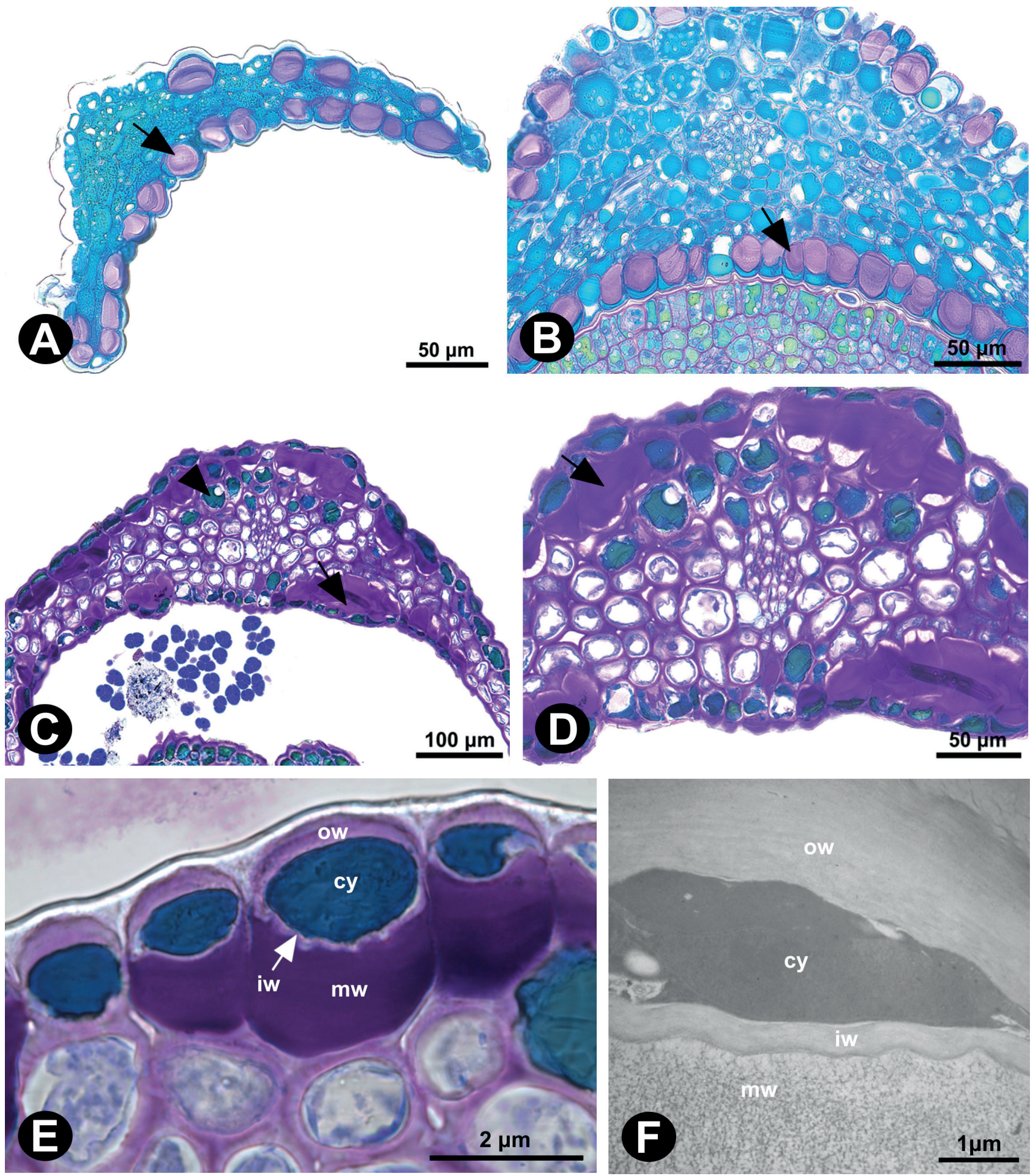

Figure 4. Occurrence of special mucilage cells in Leguminosae species. A. Mucilage cells (arrow) in the epidermis of the bract of Dimorphandra mollis (LM). B. Mucilage cells (arrow) in the epidermis of the sepal of Dimorphandra mollis (LM). C. Distribution of mucilage cells in the epidermis (arrow) of the sepal of Mimosa lewisii (LM). D. Detail of mucilage cells (arrow) of the sepal of Mimosa lewisii (LM). E. Detail of a mucilage cell in the sepal of Mimosa lewisii showing the periclinal inner mucilage cell wall (mw) and the distinct cytoplasm filled with phenolic compounds (cy) (LM). E. Ultrastructure of a epidermis cell of a sepal of Mimosa lewisii showing the internal periclinal mucilage cell wall ( $\mathrm{mw}$ ) and a distinct cytoplasm filled with phenolic compounds (cy). iw: inner periclinal cell wall; ow: outer periclinal cell wall (TEM). 

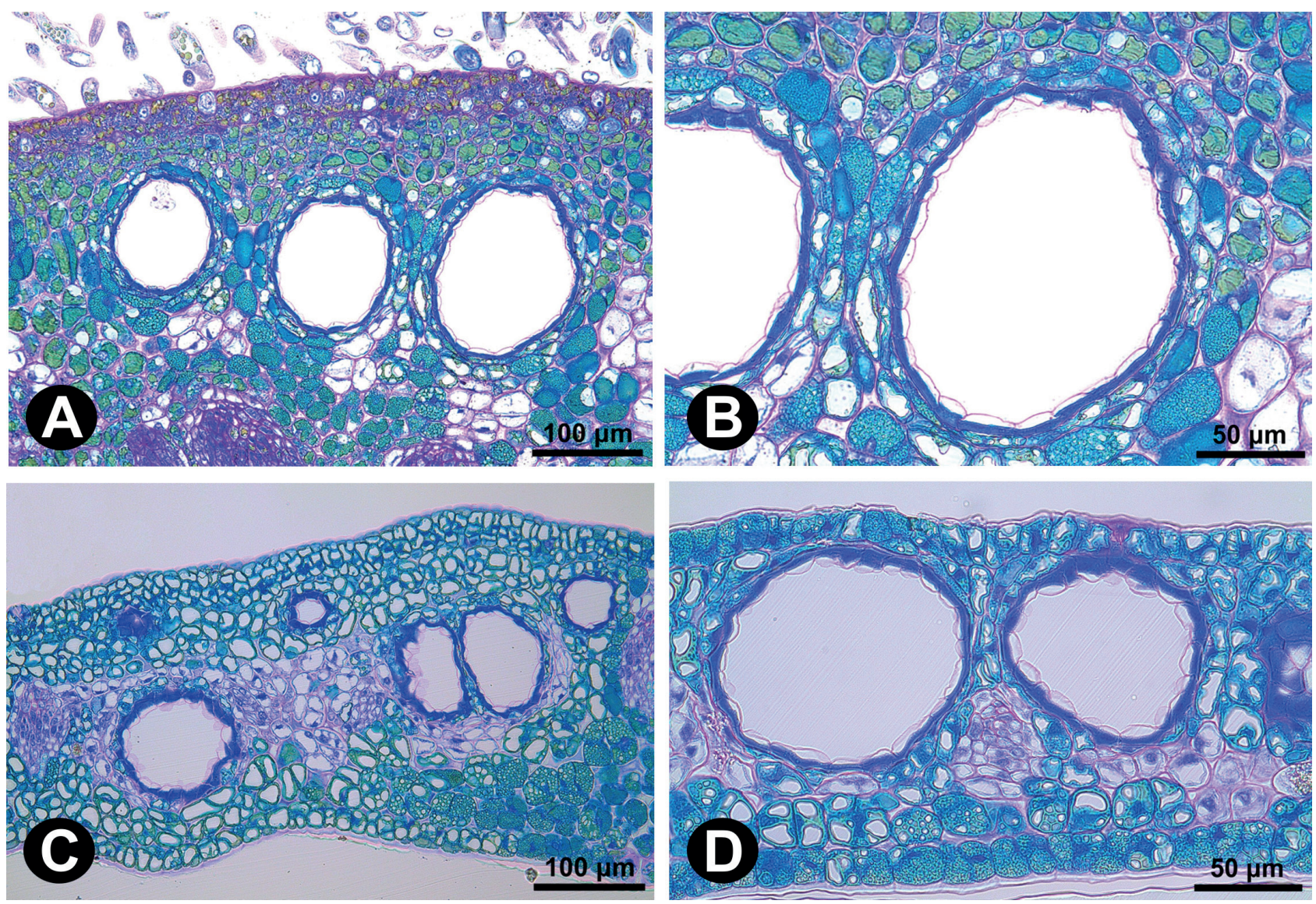

Figure 5. Occurrence of secretory cavities in Hymenaea courbaril. A. Secretory cavities in the sepals. B. Detail of the secretory cavity consisting of only one epithelial layer delimiting the rounded lumen. C. Secretory cavities in the petal. D. Detail of the secretory cavity.

have a multicellular uniseriate or multiseriate peduncle and a multicellular head. They differ in morphology, at times showing a marked distinction between head and peduncle (Fig. 6A-H) or an unclear distinction (Fig. 7A-F). Some of them accumulate phenolic compounds in the head and/ or peduncle.

\section{Discussion}

Species of the Leguminosae family show a wide diversity of secretory structures present in the floral organs during floral development. This diversity includes morphology, location and functions, with a certain type playing several roles, according to its location and secreted content.

Phenolic cells and tissues occur in species of most of the clades studied (see Fig. 2), a fact characterizing their wide distribution among Leguminosae (Lewis et al. 2005; Evert 2006). Their presence can be considered a condition with unifying value in this family instead of diagnostic one, probably because they were selected in response to general injuries provoked by herbivore attacks and exposure to UV rays (Beckman 2000; Evert 2006; Haslam 2007). In species with phenolic cells and/or tissues, the secretory cells are isolated or grouped, preferentially in the epidermis or in the subepidermal layers of floral organs, tissues that are more exposed to the environment, indicating that their location may be related to the protection of developing floral organs. In contrast, the idioblasts detected in the mesophyll close to the vascular bundles of floral organs may be related to the protection of the vascular system against the entry of pathogens into the vegetal body through the xylem (Beckman 2000).

The occurrence of mucilaginous cells has been little studied in flowers despite its potential systematic value for the groups in which they occur (see Matthews et al. 2001; Matthews \& Endress 2002; 2006). The presence of this cell type, known as 'special mucilage cells' (according to Matthew \& Endress 2006), has been seldom reported in the literature and, in Leguminosae, it was previously recorded in the sepals of Amherstia species (Caesalpinioideae s.l.). Thus, the present report of special mucilage cells in the sepals of Dimorphandra mollis (Dimorphandra p.p. clade) and Mimosa lewisii (Mimosoideae clade) (see Fig. 2) is promising for morphological, taxonomical and evolutionary studies and indicates the need to search for such secretory structures in other taxonomic groups of Leguminosae.

Two types of mucilaginous cells have been described for plants: special mucilage cells, cells with a mucilaginous inner 

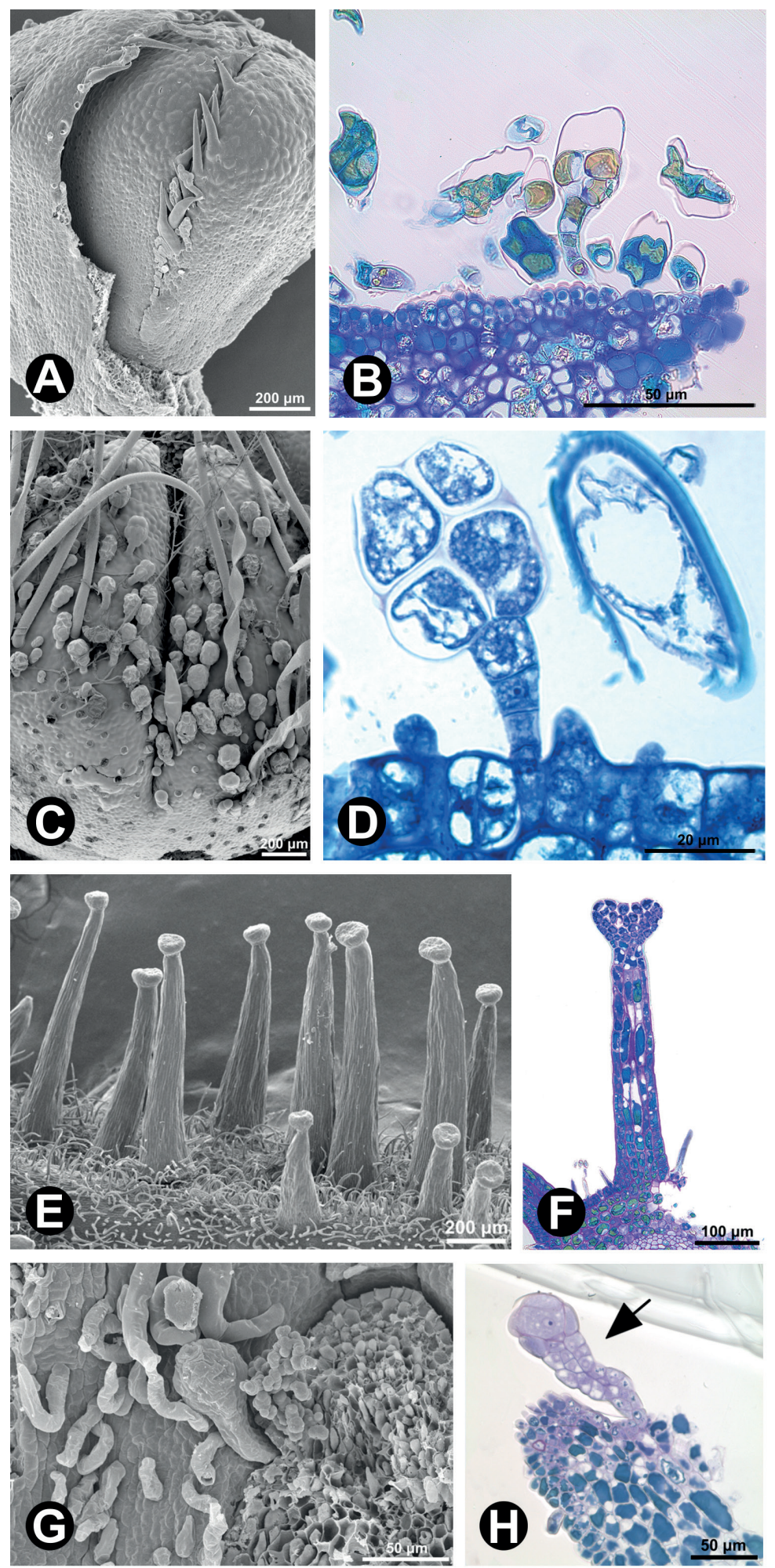

Figure 6. Multicellular secretory trichomes showing a clear distinction between peduncle and head in Leguminosae species. A. Secretory trichomes on the margins of the sepals of Calliandra brevipes (SEM). B. Detail of the anatomy of a trichome showing the multicellular uniseriate peduncle and the multicellular head, both accumulating phenolic compounds (LM). Secretory trichomes in the petals of Inga bella (SEM). D. Detail of the anatomy of an Inga bella trichome showing the multicellular and multiseriate peduncle (LM). E. Robust secretory trichomes in the axis of inflorescence of Mimosa lewisii (SEM). F. Detail of the anatomy of a Mimosa lewisii trichome showing a robust multicellular and multiseriate peduncle and a cup-shaped secretory head (LM). G. Secretory trichomes at the base of the flower bud of Tetrapleura tetraptera (SEM). H. Detail of the anatomy of Tetrapleura tetraptera trichome showing the multicellular multiseriate peduncle and the more voluminous multicellular head (LM). 

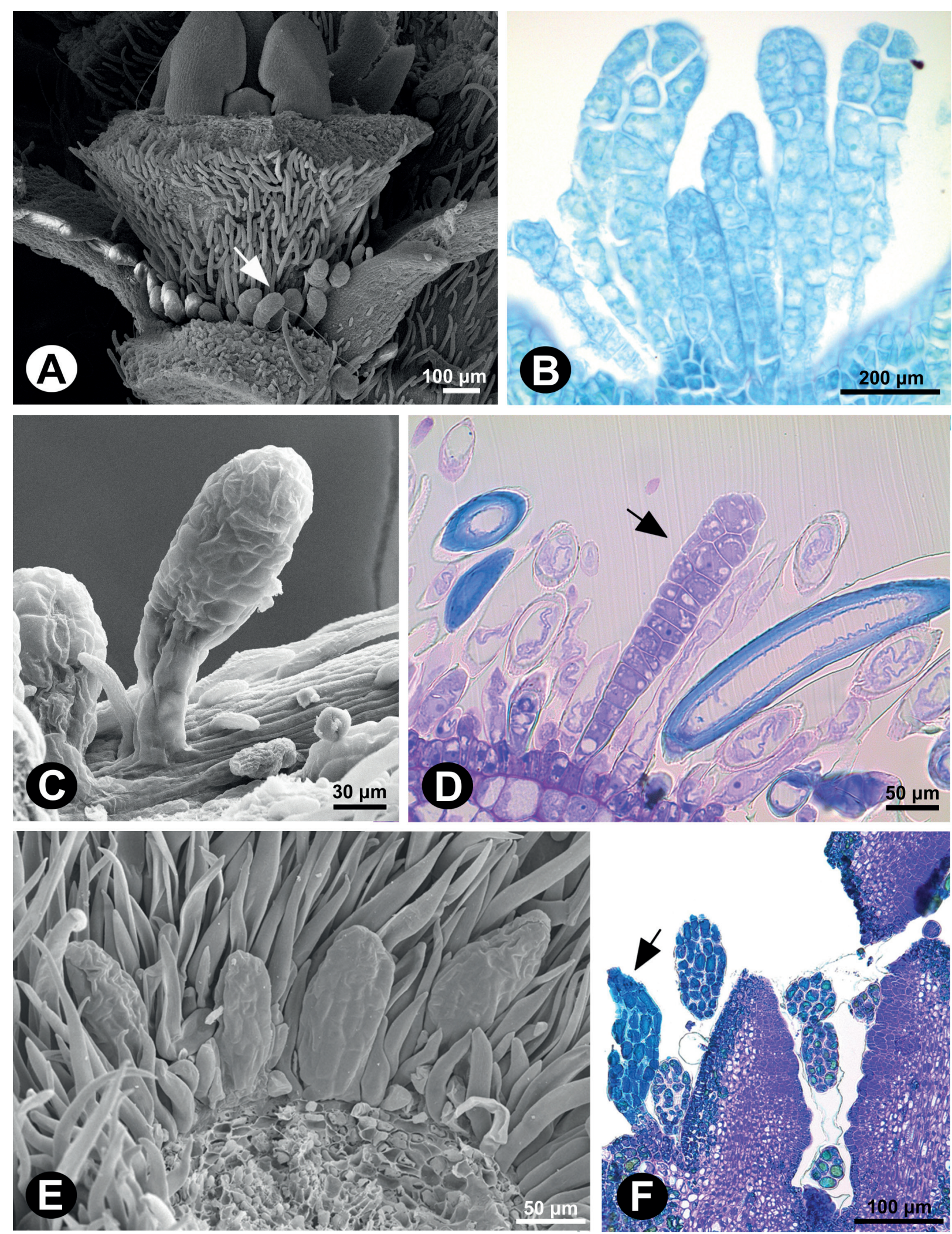

Figure 7. Multicellular secretory trichomes that do not show a clear distinction between peduncle and head (colleters) in Leguminosae species. A. Secretory trichomes grouped at the base of the floral bud of Cassia fistula (SEM). B. Anatomy of the secretory trichomes grouped at the base of the floral bud of Leptolobium elegans (LM) showing a mulicellular multiseriate peduncle and a multicellular head. C. Detail of the outer morphology of the trichome of Cassia fistula (SEM). D. Secretory trichome in the sepal of the flower bud of Platycyamus regnelli (LM) showing a multicellular multiseriate peduncle and a multicellular head. E. Secretory trichomes grouped at the base of a floral bud of Gliricidia sepium (SEM). F. Structure of the secretory trichome with a phenolic content in the bract of Mimosa lewisii (LM). 
cell wall with a distinct cytoplasm, and unspecified mucilage cells, fully mucilage cells with an indistinct cytoplasm more commonly occurring in vegetative organs (Matthew \& Endress 2006). The occurrence of special mucilage cells in flowers seems to be limited to the epidermis of the sepals (Matthews \& Endress 2006; present study). Both in flowers and in leaves, this type of mucilage cells occurs in tissues located in regions of greater exposure to the environment. In the sepals they form the epidermis on the abaxial surface and in the leaves they form the epidermis on the adaxial surface. This equivalence indicates a similar function in leaves and flowers, acting on the protection of both whorls located more internally in relation to the calyx and of mesophyll tissues. Other several hypotheses have been raised in an attempt to explain the presence of mucilage in foliar and floral cells such as: (i) a source of carbohydrates, (ii) light filtering, (iii) water retention, and (iv) reduction of transpiration (Gregory \& Baas 1989). In the special mucilage cells the mucilage is retained on the cell wall, a fact that prevents reabsorption of this exudate by the plant. However, these last three functions may be of fundamental importance for plant species living in dry environments under high light intensity, such as Dimorphandra mollis which occurs in the Cerrado, and Mimosa lewisii which is endemic in the Caatinga, among others (Mauseth 2006). In this case, the mucilaginous epidermis would reduce transpiration and filter light by forming a gelatinous layer over the internal tissues (Gregory \& Baas 1989).

In Leguminosae, secretory cavities seem to occur in phylogenetically related groups such as resin producing Detarieae (LPWG 2013, see Fig. 2) which contain species of the traditional subfamily Caesalpinioideae, such as Hymenaea courbaril (present study), H. stigonocarpa (Paiva \& Machado 2004; Paiva \& Oliveira 2004), Copaifera langsdorfii (Pedersoli et al. 2010; Rodrigues et al. 2011a, b) and C. trapezifolia (Milani et al. 2012). There are many such reports also in the Papilionoideae clade, as in the Dipterygeae (Leite et al. 2014), Amorpheae and Psoraleeae (Turner 1986) tribes, and in the genera Lonchocarpus (Teixeira et al. 2000), Dalhstedtia (Teixeira \& Rocha 2009), Myrocarpus, Myroxylon, Myrospermum (Sartori \& Tozzi 2002) and Poiretia (Müller 1984). However, few reports are available about the cavities and/or ducts in the flowers of the family. In addition to $H$. courbaril, these structures have been described in the perianth of two species of Dahlstedtia (Teixeira \& Rocha 2009; Teixeira et al. 2009), and in the perianth of Copaifera langsdorfii (Pedersoli et al. 2010), Pterodon pubescens, Dipteryx alata and Taralea oppositifolia (Papilionoideae clade) (Leite et al. 2014), and in the ovary of Hymenaea stigonocarpa (Paiva \& Oliveira 2004).

The structure of the secretory floral cavity of Hymenaea courbaril is similar to that observed in other Leguminosae (see Teixeira \& Rocha 2009; Rodrigues et al. 2011a, b; Leite et al. 2014) and is characterized by the presence of a uniseriate secretory epithelium surrounded by a parenchyma sheath. The shape of the epithelium cells can vary from rectangular to papillose or trabeculate cells in legume species. The rectangular and papillose epithelial cells are the most commonly found (present study, Teixeira \& Rocha 2009; Rodrigues et al. 2011a, b; Leite et al. 2014) whereas the trabeculate epithelial cells seems to be restricted to the Papilionoideae clade (see Turner 1986; Teixeira et al. 2000; Teixeira \& Rocha 2009). No functions have been associated to the shape of epithelial cells until now.

Ultrastructural studies of the cavities of Copaifera langsdorfii (Detarieae clade) and Pterodon pubescens (Papilionoideae clade) have demonstrated that the parenchyma sheath acts on a gradual replacement of epithelial cells that undergo lysis in the process of exudate release (Rodrigues et al. 2011a, b). Thus, the schizolysiginous cavity of $H$. courbaril (see Langenheim 2003) may also have a totipotent sheath. The resin secreting cavities of $H$. courbaril probably act in the protection against herbivores and in the sealing of plant injuries, thus preventing the entry of pathogens, in addtion to having allelopathic effects (see resin functions for plants in Langenheim 2003).

Secretory trichomes have been detected in the vegetative and reproductive organs of various leguminous plants, spread in almost all legume clades (see Fig. 2). Interestingly, although their presence is a wide condition in legumes, their distribution and morphology are highly variable and of potential systematic value for some groups such as cavitated trichomes in the genus Bauhinia (Duarte-Almeida et al. 2015; Marinho et al. 2016) and the trichomes present in species of the Caesalpinia clade (Ragonese 1973; Leelavathi \& Ramayya 1983; Lersten \& Curtis 1994; 1996; Rudall et al. 1994; Lewis \& Schrire 1995; Simpson \& Miao 1997; Pascal et al. 2000; Warwick \& Lewis 2009; Melo et al. 2010) and in the genus Mimosa (Santos-Silva et al. 2013). Our reports of floral secretory trichomes are original for 11 of the 15 species studied belonging to the Cassia, Dimorphandra, Mimosoideae and Papilionoideae clades. Reports of secretory trichomes are available for the bracts of Cassia fistula (Cassia clade) (Leelavathi \& Ramayya 1983), and their distribution was expanded in the present study to the rachis of the inflorescence, bracteoles and base of the floral receptacle.

The absence of secretory trichomes in the flowers of Caesalpinia echinata does not reflect the condition of the other species in the Caesalpinia clade, considering that Erythrostemon gilliesii and Poincianella pluviosa present these structures in the flowers and in the axis of inflorescence (Souza et al. 2013), and that other species of the clade potentially bear floral secretory trichomes since these structures have been reported to occur in the vegetative organs of approximately 100 species (Ragonese 1973; Leelavathi \& Ramayya 1983; Lersten \& Curtis 1994; 1996; Rudall et al. 1994; Lewis \& Schrire 1995; Simpson \& Miao 
1997; Pascal et al. 2000; Warwick \& Lewis 2009; Melo et al. 2010).

Some of the species studied also have secretory trichomes without a clear distinction between peduncle and head, mainly grouped at the base of the flower buds, which may be interpreted as colleters. The traditional description of the colleter only includes non-vascularized structures derived from the protoderm and from the fundamental meristem secreting water-insoluble mucilage or resin substances (Thomas 1991) that act by protecting against desiccation and by lubricating young tissues (Thomas 1991; Paiva 2009). This concept has been currently expanded to secretory structures originating only from the protoderm such as the trichomes, but with the location and production of substances that also act on the lubrication of developing organs (see Payne 1978; Fahn 1979; Thomas 1991; Renobales et al. 2001; Leitão \& Cortelazzo 2008).

Reports of colleters are still scarce in Leguminosae and are limited to embryos of species of the genus Chamaecrista (De-Paula \& Oliveira 2007), to the stipules of Hymenaea stigonocarpa (Paiva \& Machado 2006) and to the developing leaves of Copaifera langsdorfii (Paiva 2009), Mimosa (Solereder 1908), Cronocarpus (Solereder 1908) and Platymiscium (Rutishauser \& Dickison 1989). Surprisingly, floral colleters have been reported only for Copaifera langsdorfii (Pedersoli et al. 2010), Holocalyx balansae and Zollernia ilicifolia (Mansano \& Teixeira 2008) and for the genera Cassia, Chamaecrista and Senna (Souza 2014). In view of the complexity and the wide distribution of the family (Judd et al. 2009; LPWG 2013), colleters are expected to occur more frequently than reported in the literature, especially those with a morphology differing from the described pattern, or it may be assumed that other types of secretory structures may exert the same functions of lubrication and protection of apical meristems.

Among the secretory structures detected in the developing flowers of Leguminosae, the special mucilage cells, secretory cavities, secretory trichomes and the colleters have a great potential for comparative morphological studies with a systematic approach. In addition to contributing to a more robust morphological database for the new Leguminosae clades, comparisons of the diversity of these structures in the family and in closely related clades may reveal aspects of their evolution in Leguminosae. It is interesting to note, for example, that secretory trichomes with a morphology similar to that of trichomes detected in Leguminosae (multicellular uniseriate peduncle and multicellular head) occur in the abaxial base of the sepals and in the rachis of the inflorescence in Suriana maritima (Bello et al. 2007), a species of Surianaceae, considered to be a sister group of Leguminosae (see Fig. 2). Considering the complexity and wide distribution of Leguminosae, the scarcity of reports of secretory floral structures seems to be related more to deficient sampling than to the absence of such structures in the family, with the need of better investigation.

\section{Acknowledgments}

The authors thank Edimárcio da Silva Campos (Botany Laboratory/FCFRP-USP), José Augusto Maulin and Maria Dolores Seabra Ferreira (TEM Laboratory/BCMBP, FMRPUSP), Rodrigo F. Silva (Departamento de Química/FFCLRPUSP) and Rodrigo A. S. Pereira for technical assistance (Plant Ecology Laboratory/FFCLRP-USP), and Elettra Greene for the English revision. T. C. de Barros, C. R. Marinho and G. D. Pedersoli are indebted to FAPESP (process numbers 2012/01296-8, 2009/01057-0 and 2013/19459-3, respectively), and S. P. Teixeira to CNPq (process number 302204/2012-1) and FAPESP (process number 2008/57487-0).

\section{References}

Beckman CH. 2000. Phenolic-storing cells: keys to programmed cell death and periderm formation in wilt disease resistance and in general defence responses in plants? Physiological and Molecular Plant Pathology 57: 101-110.

Bello MA, Hawkins JA, PJ Rudall. 2007. Floral morphology and development in Quillajaceae and Surianaceae (Fabales), the species-poor relatives of Leguminosae and Polygalaceae. Annals of Botany 100: 1491-1505.

Bernadello G. 2007. A systematic survey of floral nectaries. In: Nicolson SW, Nepi M, Pacini E. (eds.) Nectaries and Nectar. Netherlands, Springer. p. 19-128.

Colpas FT, Oliveira DMT. 2002. Structure and ontogeny of Swartzia langsdorffii (Leguminosae) pericarp. Nordic Journal of Botany 22: 313-323.

De-Paula OC, Oliveira DMT. 2007. Ocorrência de coléteres em embriões de três espécies de Chamaecrista Moench (Fabaceae: Caesalpinioideae). Revista Brasileira de Biociências 5: 348-350.

Duarte-Almeida J, Clemente MS, Arruda RCO, Vaz AMSF, Salatino A. 2015. Glands on the foliar surfaces of tribe Cercideae (Caesapiniodeae, Leguminosae): distribution and taxonomic significance. Anais da Academia Brasileira de Ciências 87: 787-796.

Endress PK. 1994 . Diversity and evolutionary biology of tropical flowers. Cambridge, Cambridge University Press.

Evert RF. 2006. Esau's plant anatomy: meristems, cells and tissues of the plant body: their structure, function, and development. New Jersey, John Wiley \& Sons.

Fahn A. 1979. Secretory tissues in plants. London, Academic Press.

Gerrits PO. 1991. The application of glycol methacrylate in histotechnology; some fundamental principles. Groningen, Department of Anatomy and Embryology, State University Groningen.

Gregory M, Baas P. 1989. A survey of mucilage cells in vegetative organs of the Dicotyledons. Israel Journal of Botany 38: 125-174.

Haslam E. 2007. Vegetable tannins - lessons of a phytochemical lifetime. Phytochemistry 68: 2713-2721.

Healy RA, Palmer RG, Horner HT. 2009. Multicellular secretory trichome development on soybean and related Glycine gynoecia. International Journal of Plant Science 170: 444-456.

Judd WS, Campbell CS, Kellog, EA, Stevens PF, Donoghue MJ. 2009. Sistemática Vegetal: um enfoque filogenético. 3rd. edn. Porto Alegre, Artmed.

Karnovsky MJ. 1965. A formaldehyde-glutaraldehyde fixative of high osmolarity for use in eletron microscopy. Journal of Cell Biology 27: 137-138.

Kumar BKV, Prabhakar M, Ramayya N, Leelavathi P. 1986. Structure, distribution and development of cavitated trichomes in Indigofera L. (Fabaceae). Geophytology 16: 227-231.

Langenheim JH. 2003. Plant resins: chemistry, evolution, ecology, and ethnobotany. Timber Press, Inc., Portland, Oregon. 
Leelavathi P, Prabhakar M, Ramayya N. 1984. Structure and ontogeny of capitate hairs in Mimosa (L.). Geobios New Reports 3: 183-185.

Leelavathi P, Ramayya N. 1983. Structure, distribution and classification of plant trichomes in relation to taxonomy II. Caesalpinioideae. Indian Journal of Forestry 6: 43-56.

Leitão CAE, Cortelazzo AL. 2008. Structural and histochemical characterisation of the colleters of Rodriguezia venusta (Orchidaceae). Australian Journal of Botany 56: 161-165.

Leite VG, Mansano VF, Teixeira SP. 2014. Floral ontogeny in Dipterygeae (Fabaceae) reveals new insights into one of the earliest branching tribes in papilionoid legumes. Botanical Journal of the Linnean Society 174: 529-550.

Lersten NR, Curtis JD. 1994. Leaf anatomy in Caesalpinia and Hoffmannseggia (Leguminosae, Caesalpinioideae) with emphasis on secretory structures. Plant Systematics and Evolution 192: 231-255.

Lersten NR, Curtis JD. 1996. Survey of leaf anatomy, especially secretory structures, of tribe Caesalpinieae (Leguminosae, Caesalpinioideae). Plant Systematics and Evolution 200: 21-39.

Lewis GP, Schrire BD. 1995. A reappraisal of the Caesalpinia group (Caesalpinioideae: Caesalpinieae) using a phylogenetic analysis. In: Crisp MD, Doyle JJ. (eds.) Advances in legume systematics: phylogeny, part 7. Kew, The Royal Botanic Gardens. p. 41-52.

Lewis GP, Schrire B, Mackinder B, Lock M. 2005. Legumes of the world. Kew, The Royal Botanic Gardens.

Lillie RD. 1965. Histopathologic technic and practical histochemistry. 3rd. edn. New York/ Toronto/ Sydney/ London, McGraw-Hill Book Company.

LPWG - Legume Phylogeny Working Group. 2013. Legume phylogeny and classification in the 21st century: progress, prospects and lessons for other species-rich clades. Taxon 62: 217-248.

Luckow M, Miller JT, Murphy DJ, Livshultz T. 2003. A phylogenetic analysis of the Mimosoideae (Leguminosae) based on chloroplast DNA sequence data. In: Klitgaard BB, Bruneau A. (eds.) Advances in legume systematics, part 10. Kew, The Royal Botanic Gardens.

Luckow M, White PJ, Bruneau A. 2000. Relationships among the basal genera of mimosoid legumes. In: Herendeen PS, Bruneau A. (eds.) Advances in legume systematics, part 9. Kew, The Royal Botanic Gardens. p. 165-180.

Mansano VF, Teixeira SP. 2008. Floral anatomy of the Lecointea clade (Leguminosae, Papilionoideae, Swartzieae sensu lato). Plant Systematic and Evolution 273: 201-209.

Manzanilla V, Bruneau A. 2012. Phylogeny reconstruction in the Caesalpinieae grade (Leguminosae) based on duplicated copies of the sucrose synthase gene and plastid markers. Molecular Phylogenetics and Evolution 65: 149-162.

Marinho CR, Oliveira RB, Teixeira SP. 2016. The uncommon cavitated secretory trichomes in Bauhinia s.s. (Fabaceae): the same roles in different organs. Botanical Journal of the Linnean Society 180: 104122.

Marinho CR, Souza CD, Barros TC, Teixeira SP. 2014. Scent glands in legume flowers. Plant Biology (Stuttgart) 16: 215-226.

Marquiafável FS, Ferreira MDS, Teixeira SP. 2009. Novel reports of glands in Neotropical species of Indigofera L. (Leguminosae, Papilionoideae). Flora 204: 189-197.

Matthews ML, Endress PK. 2002. Comparative floral structure and systematics in Oxalidales (Oxalidaceae, Connaraceae, Brunelliaceae, Cephalotaceae, Cunoniaceae, Elaeocarpaceae, Tremandraceae). Botanical Journal of the Linnean Society 140: 321-381.

Matthews ML, PK Endress. 2006. Floral structure and systematics in four orders of rosids, including a broad survey of floral mucilage cells. Plant Systematics and Evolution 260: 199-222.

Matthews ML, Endress PK, Schönenberger J, Friis EM. 2001. A comparison of floral structures of Anisophylleaceae and Cunoniaceae and the problem of their systematic relationships. Annals of Botany 88: 439455.

Mauseth JD. 2006. Structure-function relationships in highly modified shoots of Cactaceae. Annals of Botany 98: 901-926.

Meira RMSA, Francino DMT, Ascensão L. 2014. Oleoresin trichomes of Chamaecrista dentata (Leguminosae): structure, function, and secretory products. International Journal of Plant Sciences 175: 336-345.
Melo Y, Machado SR, Alves M. 2010. Anatomy of extrafloral nectaries in Fabaceae from dry-seasonal forest in Brazil. Botanical Journal of the Linnean Society 163: 87-98.

Milani JF, Rocha JF, Teixeira SP. 2012. Oleoresin glands in copaiba (Copaifera trapezifolia Hayne: Leguminosae), a Brazilian rainforest tree. Trees 26: 769-775.

Müller C. 1984. Revisão taxonômica do gênero Poiretia Vent. (Leguminosae) para o Brasil. Dissertação de mestrado. Universidade Estadual de Campinas, Brazil.

O’Brien TP, Feder N, Mccully ME. 1964. Polychromatic staining of plant cell walls by Toluidine Blue O. Protoplasma 59: 368-373.

Paiva EAS. 2009. Ocurrence, structure and functional aspects of the colleters of Copaifera langsdorfii Desf. (Fabaceae, Caesalpinioideae). Comptes Rendus Biologies 332: 1078-1084.

Paiva EAS, Machado SR. 2004. Structural and ultrastructural aspects of ontogenesis and differentiation of resin secretory cavities in Hymenaea stigonocarpa (Fabaceae-Caesalpinioideae) leaves. Nordic Journal of Botany 24: 423-431.

Paiva EAS, Machado SR. 2006. Ontogenesis, structure and ultrastructure of Hymenaea stigonocarpa (Fabaceae: Caesalpinioideae) colleters. Revista de Biologia Tropical 54: 943-950.

Paiva EAS, Oliveira DMT. 2004. Ontogenesis of the fruit pulp layer of Hymenaea stigonocarpa (Fabaceae: Caesalpinioideae). Australian Journal of Botany 52: 677-683.

Pascal LM, Motte-Florac EF, Mckey DB. 2000. Secretory structures on the leaf rachis of Caesalpinieae and Mimosoideae (Leguminosae): implications for the evolution of nectary glands. American Journal of Botany 87: 327-338.

Paulino JV, Mansano VF, Teixeira SP. 2013. Elucidating the unusual floral features of Swartzia dipetala (Fabaceae). Botanical Journal of the Linnean Society 173:303-320.

Paulino JV, Prenner G, Mansano VF, Teixeira SP. 2014. Comparative development of rare cases of a polycarpellate gynoecium in an otherwise monocarpellate family, Leguminosae. American Journal of Botany 4: 572-586.

Payne W. 1978. A glossary of plant hair terminology. Brittonia 30: 239-255.

Pedersoli GD, Paulino JV, Leite VG, Teixeira SP. 2010. Elucidating enigmatic floral issues in Copaifera langsdorffii Desf. (Leguminosae, Caesalpinioideae). International Journal of Plant Sciences 171: 834846.

Pedersoli GD, Teixeira SP. 2016. Floral development of Parkia multijuga and Stryphnodendron adstringens, two andromonoecious mimosoid trees (Leguminosae). International Journal of Plant Sciences 1: 60-75.

Ragonese AM. 1973. Systematic anatomical characters of the leaves of Dimorphandra and Mora (Leguminosae: Caesalpinioideae). Botanical Journal of the Linnean Society 67:255-274.

Renobales G, Diego E, Urcelay B, Lopez-Quintana A. 2001. Secretory hairs in Gentiana and allied genera (Gentianaceae, subtribe Gentianinae) from the Iberian Peninsula. Botanical Journal of the Linnean Society 136: 119-129.

Reynolds ES. 1963. The use of lead citrate at high $\mathrm{pH}$ as an electron opaque stain in electronmicroscopy. Journal of Cell Biology 17: 208-213.

Rodrigues TM, Teixeira SP, Machado SR. 2011a. The oleoresin secretory system in seedlings and adult plants of copaiba (Copaifera langsdorffii Desf., Leguminosae-Caesalpinioideae). Flora 206: 585-594.

Rodrigues TM, Santos DC, Machado SR. 2011b. The role of the parenchyma sheath and PCD during the development of oil cavities in Pterodon pubescens (Leguminosae-Papilionoideae). Comptes Rendus Biologies 334: 535-543.

Rudall PJ, Myers G, Lewis GP. 1994. Floral secretory structures in Caesalpinia sensu lato and related genera. In: Ferguson IK, Tucker S. (eds.) Advances in legume systematics, part 6. Kew, The Royal Botanic Gardens. p. 41-52.

Rutishauser R, Dickison WC. 1989. Development morphology of stipules and systematics of the Cunoniaceae and presumed allies. I. Taxa with interpetiolar stipules. Botanica Helvetica 99: 149-169.

Santos-Silva J, Tozzi AMGA, Simon MF, Urquiza NG, Morales M. 2013. Evolution of trichome morphology in Mimosa (LeguminosaeMimosoideae). Phytotaxa 119: 1-20. 
Sartori ÂLB, Tozzi AMGA. 2002. Comparative leaflet anatomy in Myrocarpus Allemão, Myroxylon L. and Myrospermum Jacq. (Leguminosae Papilionoideae - Sophoreae) species. Botanical Journal of the Linnean Society 140: 249-259.

Simpson BB, Miao BM. 1997. The circumscription of Hoffmannseggia (Fabaceae, Caesalpinioideae, Caesalpinieae) and its allies using morphological and cpDNA restriction site data. Plant Systematics and Evolution 205: 157-178.

Solereder H. 1908. Systematic anatomy of the dicotyledons. Oxford, Clarendon Press.

Souza LA. 2014. Estruturas secretoras em espécies de leguminosas da subtribo Cassinae (Fabaceae, Caesalpinioideae, Cassieae). PhD Thesis, Univesidade Federal de Minas Gerais, Brazil.

Souza CD, Marinho CR, Teixeira SP. 2013. Ontogeny resolves gland classification in two caesalpinoid legumes. Trees 27: 801-813.

Teixeira SP, Castro MM, Tozzi AMGA. 2000. Secretory cavities and pellucid dots in leaflets of Lonchocarpus (Leguminosae, Papilionoideae, Millettieae). Plant Systematics and Evolution 221: 61-68.

Teixeira SP, Machado SR. 2007. Glandular dots of Caesalpinia echinata Lam. (Leguminosae): distribution, structure and ultrastructure. The Journal of the Torrey Botanical Society 134: 135-143.

Teixeira SP, Ranga NT, Tucker SC. 2009. Inflorescence and floral development of Dahlstedtia species (Leguminosae: Papilionoideae: Millettieae). Flora 204: 769-781.
Teixeira SP, Rocha JF. 2009. Oil glands in the Neotropical genus Dahlstedtia Malme (Leguminosae, Papilionoideae, Millettieae). Revista Brasileira de Botânica 32: 57-64.

Thomas V. 1991. Structural, functional and phylogenetic aspects of the colleter. Annals of Botany 68: 287-305.

Tucker SC, Rugenstein SR, Derstine K. 1984. Inflated trichomes in flowers of Bauhinia (Leguminosae: Caesalpinioideae). Botanical Journal of the Linnean Society 88: 291-301.

Tucker SC. 1993. Floral ontogeny in Sophoreae (Leguminosae, Papilionoideae). I Myroxylon (Myroxylon group) and Castanospermum (Angylocalyx group). American Journal of Botany 80: 65-75.

Tucker SC. 1994. Floral ontogeny in Sophoreae (Leguminosae, Papilionoideae). II. Sophora "sensu lato" (Sophora group). American Journal of Botany 81: 368-380.

Tucker SC. 2000. Floral development in Tribe Detarieae (Leguminosae: Caesalpinioideae): Amherstia, Brownea, and Tamarindus. American Journal of Botany 87: 1385-1407.

Tucker SC. 2003. Floral development in Legumes. Plant Physiology 131: 911- 926.

Turner GW. 1986. Comparative development of secretory cavities in the Tribes Amorpheae and Psoraleeae (Leguminosae: Papilionoideae). American Journal of Botany 73: 1178-1192.

Warwick MC, Lewis GP. 2009. A revision of Cenostigma (Leguminosae - Caesalpinioideae - Caesalpinieae), a genus endemic to Brazil. Kew Bulletin 64: 135-146. 